\title{
Low pressure metamorphism in the Orrs Island - Harpswell Neck area, Maine
}

\author{
Gilbert R. Dunn ${ }^{*}$ \\ and \\ Helen M. Lang** \\ Department of Geology and Geography, West Virginia University, Morgantown, West Virginia 26506
}

Date Received April 18, 1988

Date Accepted September 6, 1988

\begin{abstract}
The Orrs Island-Harpswell Neck area on the southern Maine coast experienced one major low-pressure metamorphic event, which was synchronous with $\mathrm{D}_{2}$ deformation. Metamorphic grade increases from southwest to northeast toward plutons outside the area. Isograds in pelitic rocks divide the area into gamet, staurolite, staurolite-andalusite, staurolite-sillimanite, and sillimanite zones. At the sillimanite isograd, andalusite began to be replaced by coarse-grained muscovite to form prograde pseudomorphs, while sillimanite formed in the matrix. At slightly higher grade, staurolite was replaced by muscovite pseudomorphs. and additional sillimanite formed.

Isograd riactions deduced from changes in AFM topology were located in pressure-temperature space on the basis of experimental and thermodynamic data. The resulting petrogenetic grid constrains the pressure during metamorphism to between 2.3 and $3.0 \mathrm{kbars}(230$ and $300 \mathrm{MPa})$. Estimated temperature ranges for each of the metamorphic zones are as follows: garnet zone, $<500^{\circ} \mathrm{C}$; staurolite zone, 500 to $530^{\circ} \mathrm{C}$; staurolite-andalusite zone, 530 to $570^{\circ} \mathrm{C}$; staurolite-sillimanite zone, 570 to $590^{\circ} \mathrm{C}$; and sillimanite zone, $>590^{\circ} \mathrm{C}$. Metamorphism in the Orrs Island-Harpswell Neck area is similar to $\mathrm{M}_{3}$ metamorphism in west-central Maine, because both events occurred at pressures where staurolite gave way to sillimanite at high grade, and both were related to plutons. Metamorphism in the study area differs from $M_{3}$ in west-central Maine in that it produced andalusite at intermediate grade.
\end{abstract}

Sur la côte méridionale du Maine, la région d'Ors Island-Harpswell Neck subit un épisode majeur de métamorphisme à basse pression synchrone de la déformation $\mathrm{D}_{2}$. Le degré de métamorphisme augmente du sud-ouest au nord-est en direction des plutons hors de la région. Les isogrades des pélites définissent dans cette région des zones à grenat, staurotide, staurotideandalousite, staurotide-sillimanite, et à sillimanite. A l'isograde de la sillimanite, l'andalousite commença à être remplacée par une muscovite grossière pour former des pseudomorphes progrades, alors que la sillimanite se forma dans la matrice. A un degré un peu plus élevé, des pseudomorphes de muscovite remplacèrent la staurotide et d'autre sillimanite apparût.

On situa dans l'espace pression-tempér ature les réactions d'isogrades déduites des changements dans la topologie AFM à partir de données expérimentales et thermodynamiques. Le champ pétrogénétique résultant ceme la pression durant le métamorphisme entre 2.3 et $3.0 \mathrm{kbars}(230$ et $300 \mathrm{MPa}$ ). Voici l'étendue estimée des températures pour chaque zone métamorphique: zone à grenat $<500^{\circ} \mathrm{C}$, zone à staurotide 500 à $530^{\circ} \mathrm{C}$, zone à staurotide-andalousite 530 à $570^{\circ} \mathrm{C}$, zone à staurcitide-sillimanite 570 à $590^{\circ} \mathrm{C}$ et zone à sillimanite $590^{\circ} \mathrm{C}$. Le métamorphisme dans la région d'Orrs Island-Harpswell Neck rappelle le métamorphisme $\mathrm{M}_{3}$ du centre et de l'ouest du Maine en ce que l'un et l'autre épisodes prirent place à des pressions auxquelles la sillimanite se substitua à la staurotide à un haut degré et que tous deux sont liés à des plutons. Le métamorphisme dans la région étudiée differe de $\mathrm{M}_{3}$ du centre et de l'ouest du Maine par la production d'andalousite à un degré intermédiaire.

[Traduit par le joumal]

\section{INTRODUCTION}

Although metamorphism in much of New England has been studied intensively (e.g., Thompson and Norton, 1968; Holdaway et al., 1982; Guidotti et al., 1983), the southeastern coast of Maine is one of the least studied areas in the Northern Appalachi-

'Current address: Weston, 955 L'Enfant Plaza, S.W., 8th Floor, Washington, D.C. 20024

**Contact for reprint requests ans (Guidotti et al., 1983). The Orrs Island-Harpswell Neck area (Figs. 1,2) was chosen for detailed metamorphic study because it contains abundant pelitic rocks and has near-continuous coastal exposure. Rocks range from chlorite through sillimanite grade, with andalusite present in many samples (Hussey, 1971). The study area is in Casco Bay northeast of Portland, Maine, and includes Harpswell Neck, Bailey Island, Orrs Island, and the western part of Sebascodegan Island (Fig. 1). It is located east of the Norumbega fault zone (Fig. 2 and Osberg et al., 1985). 

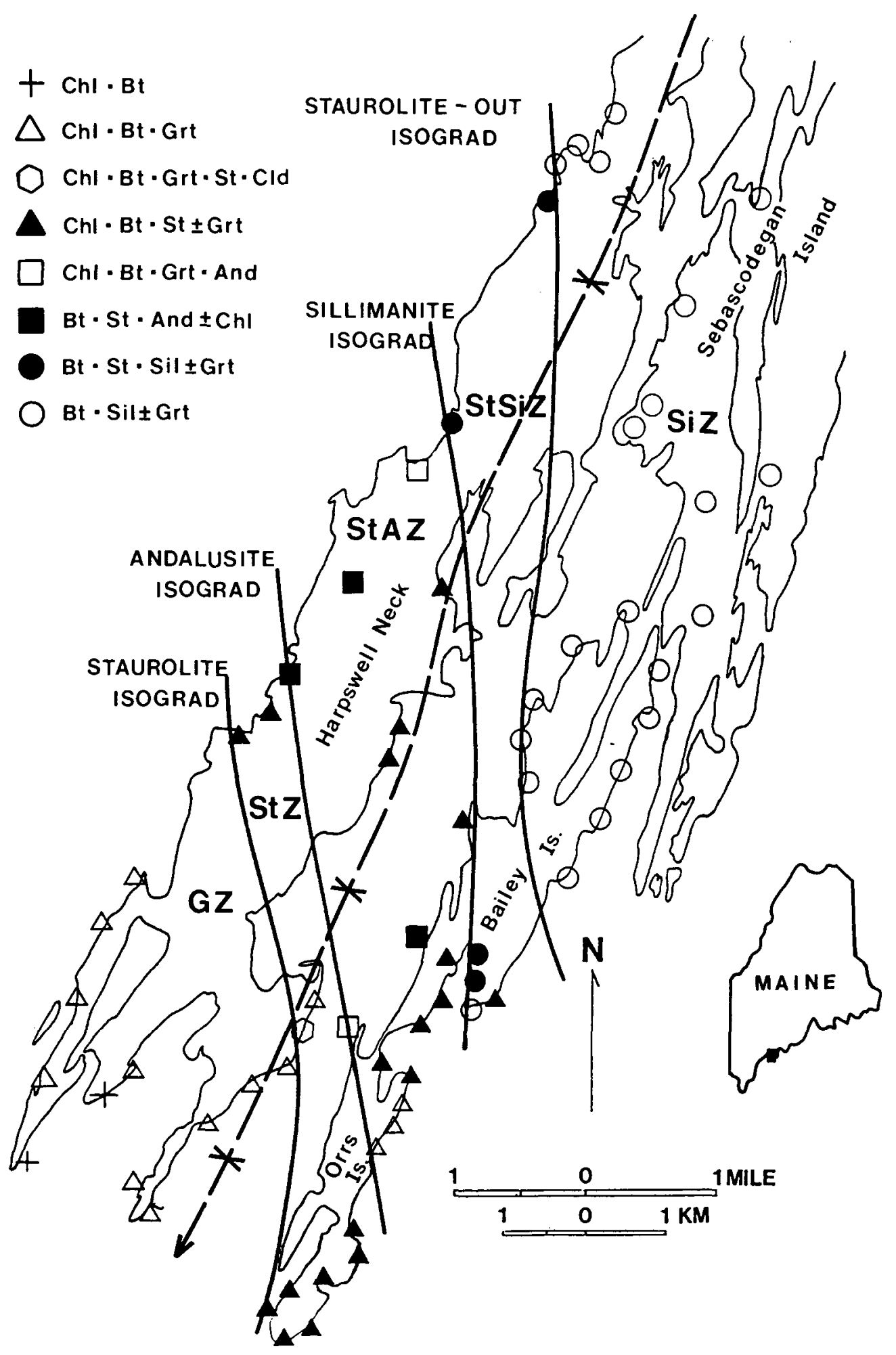

Fig. 1. Metamorphic assemblage map. Presumed equilibrium metamorphic assemblages in pelitic rocks are symbolized as shown on the figure. All samples contain muscovite, quartz, plagioclase, and opaque minerals (graphite, ilmenite and/or magnetite) in addition to the index minerals shown. Isograds (heavy solid lines) are based on the first appearance or disappearance of an index mineral. Zones are indicated as follows: $\mathrm{GZ}=$ garnet zone, $\mathrm{StZ}=$ staurolite zone, $\mathrm{StAZ}=$ staurolite-andalusite zone, $\mathrm{StSiZ}=$ staurolite-sillimanite zone, SiZ= sillimanite zone. The heavy dashed line is the axis of the Harpswell Sound Syncline. (Mineral abbreviations after $\mathrm{Kretz}, 1983$ : And $=$ andalusite, $\mathrm{Bt}=$ biotite, $\mathrm{Chl}=\mathrm{chlorite}$, $\mathrm{Cld}=$ chloritoid, $\mathrm{Grt}=$ gamet, $\mathrm{Ky}=$ kyanite, $\mathrm{Qtz}=$ quartz, $\mathrm{Sil}=$ sillimanite, $\mathrm{St}=$ staurolite). Inset map of Maine shows the location of the study area. 


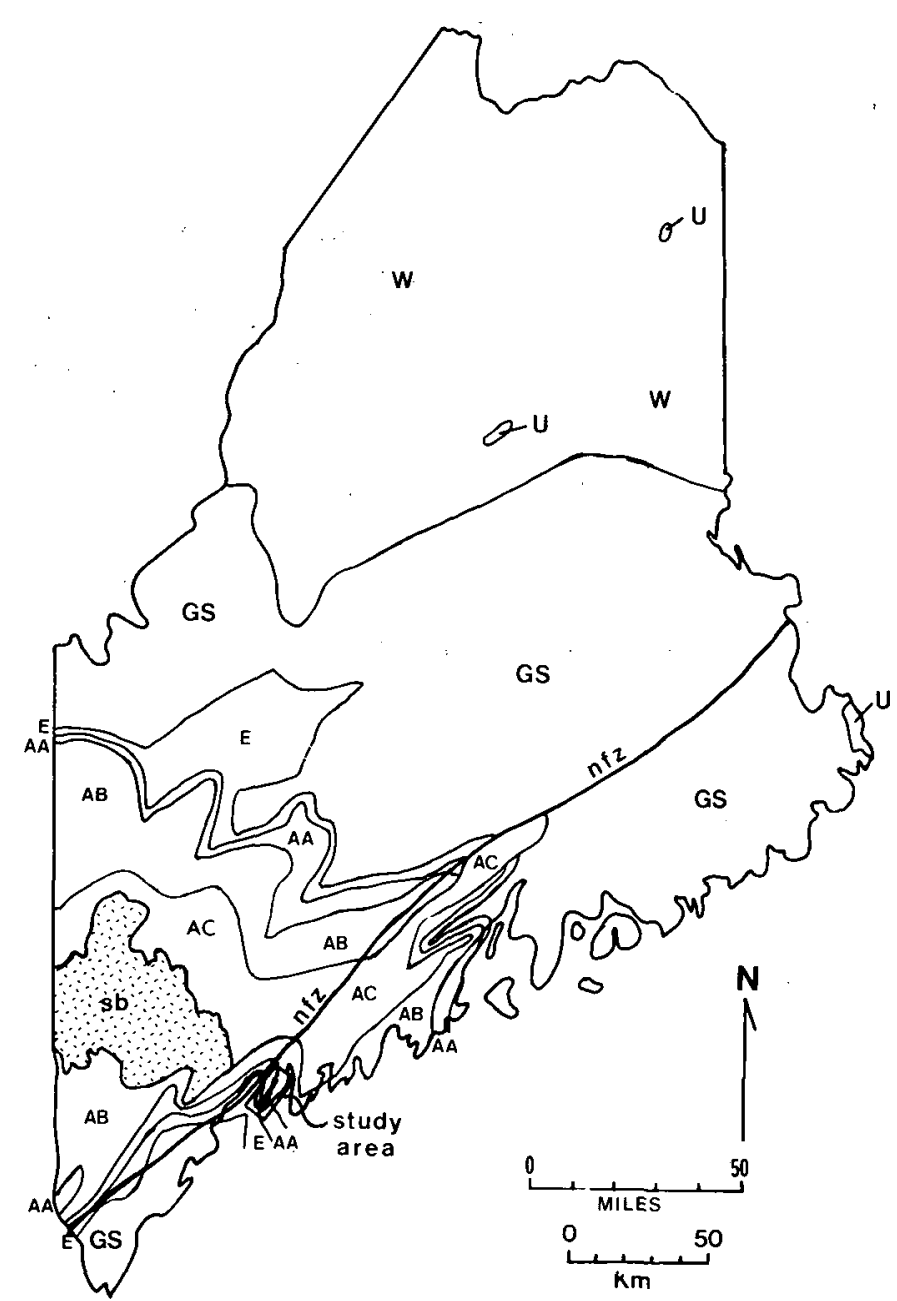

Fig. 2. Generalized metamorphic map of Maine (after Guidotti, 1985). $\mathrm{U}=$ unmetamorphosed, $\mathrm{W}=$ weakly metamorphosed, $\mathrm{GS}=$ greenschist facies, $\mathrm{E}=$ epidote-amphibolite facies, $\mathrm{AA}=$ low-rank amphibolite facies, $A B=$ medium-rank amphibolite facies, $A C=$ high-rank amphibolite facies, $\mathrm{nf} \mathrm{z}=$ Norumbega fault zone, $\mathrm{sb}$ (patterned area) = Sebago Batholith (other plutons are present, but not shown on this map).

Other detailed studies of metamorphism in Maine have been done in areas on the west side of the Norumbega fault zone.

\section{PREVIOUS WORK}

Numerous detailed studies of metamorphism have been done in west-central Maine and New Hampshire (e.g., Osberg, 1968, 1971, 1974; Guidotti, 1970a, b, 1974; Novak and Holdaway, 1981; Thomson, 1985; Thomson and Guidotti, in press; Chamberlain and Lyons, 1983). On the basis of such studies and additional reconnaissance work Guidotti (1985) and Guidotti et al. (1983) produced a generalized metamorphic map of Maine and described the metamorphic history of Maine. The regional metamorphic map of Maine (Fig. 2, after Guidotti, 1985) shows a pattern of ESE-trending isograds that seem to be part of one "nearly synchronous" event that affected all of southem Maine (Guidotti et al., 1983). Metamorphic grade increases from both the north and the south toward the area occupied by the Sebago Batholith (Fig. 2). Guidotti et al. (1983) noted four northeast-trending lobes of higher grade metamorphism that are outlined by the boundary between the low-rank amphibolite facies (AA) and the medium-rank amphibolite facies (AB) (Fig. 2). The Orrs Island-Harpswell Neck study area includes rocks of the epidote-amphibolite (E), low-rank amphibolite (AA), and medium-rank amphibolite (AB) facies (Guidotti, 1985; Guidotti et al., 1983).

Holdaway et al. (1982) described four Acadian metamorphic events that affected west-central Maine to which metamorphic events in the Orrs Island-Harpswell Neck area may be related. The first metamorphic event in west-central Maine $\left(M_{1}\right)$ caused low-grade regional metamorphism to chlorite grade. This event produced an $S_{1}$ schistosity ( $S_{0}$ is bedding), which is axial planar to large northeast-trending folds. The second event $\left(\mathrm{M}_{2}\right)$ was a regional metamorphism that produced staurolite, andalusite, and locally cordierite (Holdaway et al., 1982). $\mathrm{M}_{2}$ postdated a prominent slip cleavage $\left(S_{2}\right)$. No sillimanite-grade rocks produced by $\mathrm{M}_{2}$ have yet been identified, and this event shows no relation to exposed plutons. A third regional metamorphic event $\left(\mathrm{M}_{3}\right)$, which commonly affected $\mathrm{M}_{2}$ assemblages, can be recognized in some parts of westem Maine. Andalusite was not stable in any of the assemblages attributed to $\mathrm{M}_{3}$ (Holdaway et al., 1982). Cordierite is absent from $M_{3}$ assemblages, except in the most magnesian sulfidic rocks. Metamorphism during $\mathrm{M}_{3}$ involved staurolite+chlorite and sillimanite and was related to the intrusion of plutonic rocks (Holdaway et al., 1982). Guidotti et al. (1983) attributed the isograds of Figure 2 to $\mathrm{M}_{3}$. Holdaway et al. (1988) discounted $\mathrm{M}_{4}$ as originally described in Holdaway $e t$ al. (1982). There is, however, a well-documented post-M metamorphic event related to the Hercynian (Alleghenian) Sebago Batholith (Thomson, 1985; Lux and Guidotti, 1985; Guidotti et al., 1986), to which Holdaway et al. (1988) referred as $M_{s} . M_{s}$ caused metamorphism to sillimanite-orthoclase grade north of the Sebago Batholith (Guidotti et al., 1986) and kyanite-grade metamorphism south of the Sebago Batholith (Thomson, 1985; Thomson and Guidotti, in press). More recent studies (Lux and Guidotti, 1985; Lux et al., 1986) indicated that there is no one set of metamorphic events $\left(M_{1}, M_{2}, M_{3}\right)$ that applies to all of southem Maine. High-grade events in different areas were related to magmatic intrusions of slightly different ages and cannot be regionally correlated (C.V. Guidotti, personal communication, 1988).

Hussey $(1971,1985)$ produced a bedrock geologic map of the Orrs Island-Harpswell Neck area. He interpreted stratigraphic relationships, mapped the structural geology, and determined the deformational history. Although he did not study metamorphic petrology in detail, Hussey (1971) mapped preliminary isograds in the Orrs Island-Harpswell Neck area.

\section{STRATIGRAPHY AND STRUCTURE}

Katz (1917) named the sequence of pelitic metasedimentary and mafic metavolcanic rocks that are exposed around Casco Bay (including those in the study area) the Casco Bay Group. The Casco Bay Group of Katz (1917) includes, in ascending order, the Cape Elizabeth Formation, Spring Point Greenstone, Diamond Island Formation, Scarboro Formation, Spurwink Limestone, and the Jewell Formation. Hussey (1968) included the Cushing Formation as the basal formation of the Casco Bay Group. All of 
the units of the Casco Bay Group are exposed in the Orrs IslandHarpswell Neck area (Hussey, 1971); however, most of the area is underlain by rocks of the Cape Elizabeth Formation. The Cape Elizabeth Formation consists of a sequence of quartzose metapelites with interbedded units varying from 1.5 to $35 \mathrm{~m}$ thick of muscovite-biotite-garnet-staurolite and/or sillimanite schist (Hussey, 1971).

Rocks of the study area are multiply deformed (Hussey, 1971). Hussey et al. (1986) proposed that the area was affected by early large-scale recumbent folds $\left(F_{1}\right)$, which are not observable in the study area. Northeast-trending upright folds $\left(\mathrm{F}_{2}\right)$, such as the Harpswell Sound syncline (Fig. 1), are responsible for the outcrop pattern in the study area. Compositional layering generally strikes northeast with a nearly vertical dip. Bedding is commonly overprinted by $\mathrm{S}_{2}$ schistosity, which is axial-planar to the $F_{2}$ folds. $S_{2}$ also strikes northeast (N20E to N45E) with a nearly vertical dip.

A third deformation folded $\mathrm{S}_{2}$ into small-scale, asymmetric folds in quartz-rich pelites $\left(\mathrm{F}_{3}\right)$, and formed crenulation cleavage in micaceous pelites ( $\mathrm{S}_{3}$; Hussey et al., 1986). Later north-south deformation formed another set of crenulation cleavages with fold hinges that trend northwest (N40W to N65W) and plunge nearly vertically. Kink bands with fold hinges that trend to the northeast and plunge vertically are common in the Cape Elizabeth Formation. These kink bands were also formed by a later deformation (Hussey, 1971).

\section{METAMORPHIC MINERALOGY AND TEXTURES}

The metamorphic assemblages from samples collected in the Orrs Island-Harpswell Neck area are indicated by symbols on Figure 1 (Dunn, 1988). Microstructural criteria proposed by Vermon (1977) were used to determine equilibrium metamorphic assemblages. His criteria are: (1) all minerals are in contact with each other, and show no evidence of mutual replacement, (2) the porphyroblasts and inclusions have shapes that show minimum interfacial free energy, and (3) no evidence of replacement of one mineral by another is observable. Metamorphic isograds(Fig. 1) are mapped on the basis of the first appearance or disappearance of index minerals, which are caused by changes in AFM topology. Zones between the isograds are named for coexisting index minerals.

\section{Garnet Zone}

Pelitic rocks in the southwestem portion of the study area contain the lowest grade mineral assemblage: chlorite, biotite, garnet, muscovite, quartz, plagioclase, and opaque minerals (magnetite, ilmenite, and graphite). Because most rocks contain garnet, this zone is designated the garnet zone. Garnet in this zone occurs as anhedral to euhedral grains that range in size from 0.1 to $2 \mathrm{~mm}$. Garnet is poikiloblastic and contains inclusions of quartz, muscovite, biotite, and/or opaque minerals. Andalusite occurs in quartz veins in this zone (A.M. Hussey II, personal communication, 1988), indicating that andalusite was the stable $\mathrm{Al}_{2} \mathrm{SiO}_{5}$ polymorph. Andalusite does not, however, occur with biotite in normal pelitic rocks, so the zone is referred to as the garnet zone for pelitic rocks. (This accounts for the difference in zone designation in Hussey, 1971.)

\section{Staurolite Zone}

The northeastern margin of the gamet zone is the staurolite isograd (Fig. 1), which is defined by the first appearance of staurolite in pelitic rocks. Beyond the staurolite isograd is a narrow staurolite zone in which some pelitic schists contain staurolite, but none contain andalusite or sillimanite. The complete assemblage of the staurolite zone is staurolite, chlorite, garnet, biotite, muscovite, quartz, plagioclase, and opaque minerals. Staurolite occurs as anhedral to euhedral poikiloblasts that range in size from 0.5 to $40 \mathrm{~mm}$. Chloritoid comprises $10 \%$ of samples from one outcrop within the staurolite zone (Fig. 1). Again, andalusite occurs in quartz veins in this zone (A.M. Hussey II, personal communication, 1988), but because andalusite does not occur with biotite in pelitic schists the zone is referred to as the staurolite zone for pelitic rocks.

\section{Staurolite-Andalusite Zone}

The first appearance of andalusite in pelitic rocks (Fig. 1) defines the andalusite isograd and the northeastern margin of the staurolite zone. Northeast of this isograd, some samples contain staurolite and andalusite that are in apparent textural equilibrium. In these samples, staurolite and andalusite share sharp, euhedral contacts and lack evidence for replacement (Fig. 3). This zone is, therefore, referred to as the staurolite-andalusite zone (Fig. 1). Neither staurolite nor andalusite is replaced by coarse-grained muscovite pseudomorphs in this zone. This contrasts with higher grade zones to the east. The complete equilibrium assemblage for the staurolite-andalusite zone is andalusite, staurolite, chlorite, garnet, biotite, muscovite, quartz, plagioclase, and opaque minerals. Andalusite in the stauroliteandalusite zone occurs as subhedral to anhedral poikiloblasts that range in size from 3 to $80 \mathrm{~mm}$. Inclusions may consist of any minerals that occur in the staurolite zone.

\section{Staurolite-Sillimanite Zone}

The beginning of the staurolite-sillimanite zone is defined by the sillimanite isograd, which is based on the first appearance of fibrolitic sillimanite (Fig. 1). At the same isograd, andalusite begins to be replaced by coarse-grained, randomly oriented muscovite. Staurolite is present in most samples and apparently remained stable to a slightly higher grade. Staurolite shows no indication of disequilibrium with sillimanite and is not rimmed by coarse-grained muscovite. The common equilibrium assemblage in the staurolite-sillimanite zone is sillimanite, staurolite, garnet, biotite, muscovite, quartz, plagioclase, and opaque minerals. Sillimanite in the staurolite-sillimanite zone occurs as 0.01 to $0.5 \mathrm{~mm}$ bundles of light-brown fibrolite. Fibrolite nucleated on biotite and is commonly aligned with the schistosity. Bundles of randomly oriented sillimanite are observed, and, in a few samples, sillimanite directly replaced andalusite. 


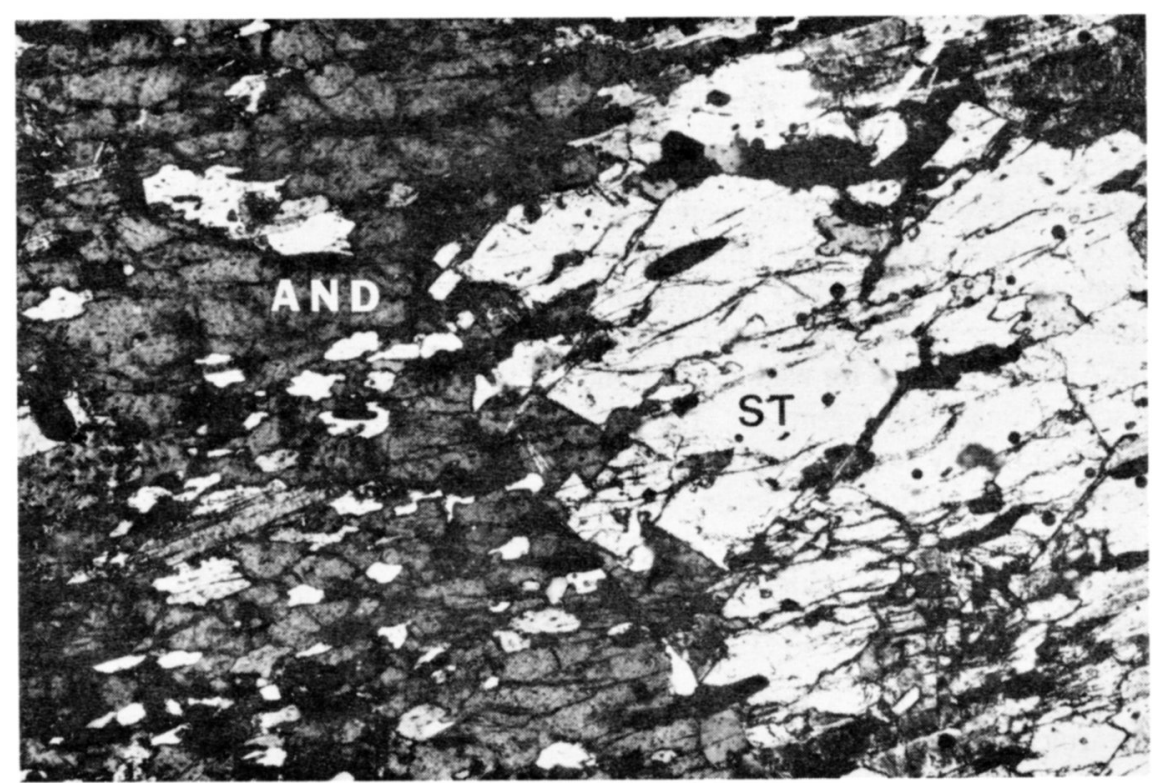

Fig. 3. Photomicrograph that shows textural equilibrium between staurolite (ST) and andalusite (AND) in a sample from the staurolite-andalusite zone. Poikiloblastic andalusite (near extinction) fills the left half of the photograph. (Crossed-polarized light, field width is $3.5 \mathrm{~mm}$ )

\section{Sillimanite Zone}

The next isograd is the staurolite-out isograd (Fig. 1). It is placed where staurolite began to be replaced by coarse- grained muscovite. Although optically continuous staurolite commonly remains in the cores of coarse-grained muscovite pseudomorphs, it was apparently unstable with sillimanite, and is not included in the equilibrium assemblage. The zone beyond this isograd, the sillimanite zone, is the highest grade zone in the study area (Fig. 1). The characteristic assemblage of the sillimanite zone is sillimanite, garnet, biotite, muscovite, quartz, plagioclase, and opaque minerals. Sillimanite (1-10\%) is more abundant than in the staurolite-sillimanite zone. It commonly occurs as 0.5 to 5.0 $\mathrm{mm}$ bundles of randomly oriented fibrolite; however, prismatic grains of sillimanite up to $0.1 \mathrm{~mm}$ in diameter are also present.

\section{Pseudomorphs and Replacement}

Rocks in the Orrs Island-Harpswell Neck area preserve textural evidence of both prograde and retrograde metamorphism. The first appearance of fibrolitic sillimanite (sillimanite isograd) occurs in the same samples where muscovite began to replace andalusite. The muscovite pseudomorphs of andalusite that resulted were apparently a product of the prograde replacement of andalusite by sillimanite via a complex reaction (Carmichael, 1969; Guidotti, 1970a). The extent of replacement is variable, and the pseudomorphs commonly have cores of andalusite.

Coarse-grained muscovite pseudomorphs after staurolite similar to those described by Guidotti $(1968,1970 \mathrm{a}, 1974)$ are observed beyond the staurolite-out isograd. The abundance of sillimanite also increases beyond this isograd indicating that staurolite+quartz became unstable relative to sillimanite with increasing grade. The extent of replacement of andalusite and staurolite by muscovite increases with grade, and in the sillimanite zone, some pseudomorphs contain only coarse-grained muscovite. In these cases, it is difficult to determine whether the pseudomorphs replaced staurolite or andalusite.

Minor effects of retrograde metamorphism are observed throughout the study area. In some samples, andalusite or staurolite is partially replaced by fine-grained white mica and/or chlorite. Fine-grained pseudomorphs after alumino-silicates and staurolite, which are commonly observed in metapelites (e.g., Guidotti, 1970b; Kwak, 1971; Lang and Rice, 1985a; Mohr et al., 1986), are interpreted as evidence for retrograde metamorphism. In the Orrs Island-Harpswell Neck area, such replacement is most common in the staurolite-sillimanite and sillimanite zones, but also occurs in the lower grade zones. Another effect of retrograde metamorphism is replacement of biotite by $\mathrm{Fe}$-rich chlorite in some samples.

\section{Timing of Crystallization}

Inclusions in porphyroblastic minerals preserve evidence for transposition of a near-horizontal $S_{1}$ to a near-vertical $S_{2}$ by progressive crenulation cleavage development (Bell and Rubenach, 1983; Bell et al., 1986). Preservation of successively later stages of crenulation cleavage development in biotite, garnet, staurolite, and andalusite, and the post-kinematic nature of sillimanite (Dunn, 1988; Lang and Dunn, in preparation) indicate that metamorphism was truly progressive. That is, lower grade minerals developed sequentially before higher grade minerals in the same rock. 


\section{METAMORPHIC REACTIONS}

Changes in mineral assemblages and mineral abundance with metamorphic grade can be shown on the Thompson (1957) AFM diagram as changes in tie-line configurations. Topology changes on the AFM diagram indicate a discontinuous reaction, which forms a new phase or combination of phases and destroys old ones. Reaction isograds on the Earth's surface are generally the result of discontinuous reactions (Thompson, 1957; Carmichael, 1970). The AFM topologies for each zone in the study area are shown schematically in Figure 4. The first appearance of staurolite in the study area is observed in the equilibrium assemblage staurolite, chloritoid, chlorite, biotite. Because chloritoid was found in only one small area, and because extra components may have stabilized the chloritoid-bearing assemblage, most staurolite is postulated to have formed by the reaction:

$$
\mathrm{Chl}+\mathrm{Grt}+\mathrm{Ms}=\mathrm{St}+\mathrm{Bt}+\mathrm{Qtz}+\mathrm{H}_{2} \mathrm{O}(1)
$$

(abbreviations after Kretz, 1983; see caption of Fig. 1). Reaction 1 relates the common garnet zone assemblages to the common staurolite zone assemblages (Fig. 4a, b), and marks the transition from the garnet to the staurolite zone. Equilibrium assemblages in the staurolite zone commonly contain coexisting garnet and chlorite (Fig. 1). If chlorite and gamet coexist at equilibrium, the common staurolite zone assemblage contains four AFM phases $(\mathrm{Chl}+\mathrm{Bt}+\mathrm{Grt}+\mathrm{St})$. The garnet in this assemblage is probably stabilized by extra components ( $\mathrm{Mn}$ or $\mathrm{Ca}$ ) that allow this four AFM phase assemblage to exist at equilibrium (Lang and Rice, 1985b; Spear and Cheney, 1986).

The transition from staurolite to staurolite-andalusite zone is defined by the first appearance of andalusite. The andalusiteproducing reaction, deduced from the AFM topology (Fig. 4b, c) is of the form:

$$
\mathrm{St}+\mathrm{Chl}+\mathrm{Ms}=\mathrm{And}+\mathrm{Bt}+\mathrm{Qtz}+\mathrm{H}_{2} \mathrm{O}(2)
$$

Equilibrium assemblages in the staurolite-andalusite zone commonly contain four AFM phases (Fig. 1). In the Chl+Bt+Grt+St and $\mathrm{Chl}+\mathrm{Bt}+\mathrm{Grt}+\mathrm{And}$ assemblages, garnet may be stabilized by extra components; therefore, tie-lines to garnet are dashed in Figure 4c. The four AFM phase assemblage, $\mathrm{Chl}+\mathrm{Bt}+\mathrm{St}+\mathrm{And}$, may have buffered $\mathrm{f}_{\mathrm{H} 2 \mathrm{O}}$ in the metamorphic fluid by reaction (2). This assemblage is comparable to the "transition zone" assemblage of Guidotti (1974) and Lang and Rice (1985b). These investigators made quantitative estimates of coefficients in reactions similar to reaction (2).

Sillimanite first appeared in the Orrs Island-Harpswell Neck area by the polymorphic transition:

$$
\text { And = Sil (3) }
$$

which is the net reaction between the assemblages of the staurolite-andalusite and the staurolite-sillimanite zones (Fig. 4c, d). Direct replacement of andalusite by sillimanite is not commonly observed. Instead, andalusite is rimmed by coarse- grained muscovite, and fibrolitic sillimanite is found elsewhere in the sample. Carmichael (1969) described a similar kyanite to sillimanite transition, which involved two coupled ion-exchange reactions. The four-AFM-phase assemblage, $\mathrm{Chl}+\mathrm{Bt}+\mathrm{St}+\mathrm{Sil}$, is observed in one sample from the staurolite-sillimanite zone. This assemblage may have been capable of buffering $\mathrm{f}_{\mathrm{H} 20}$ by a reaction

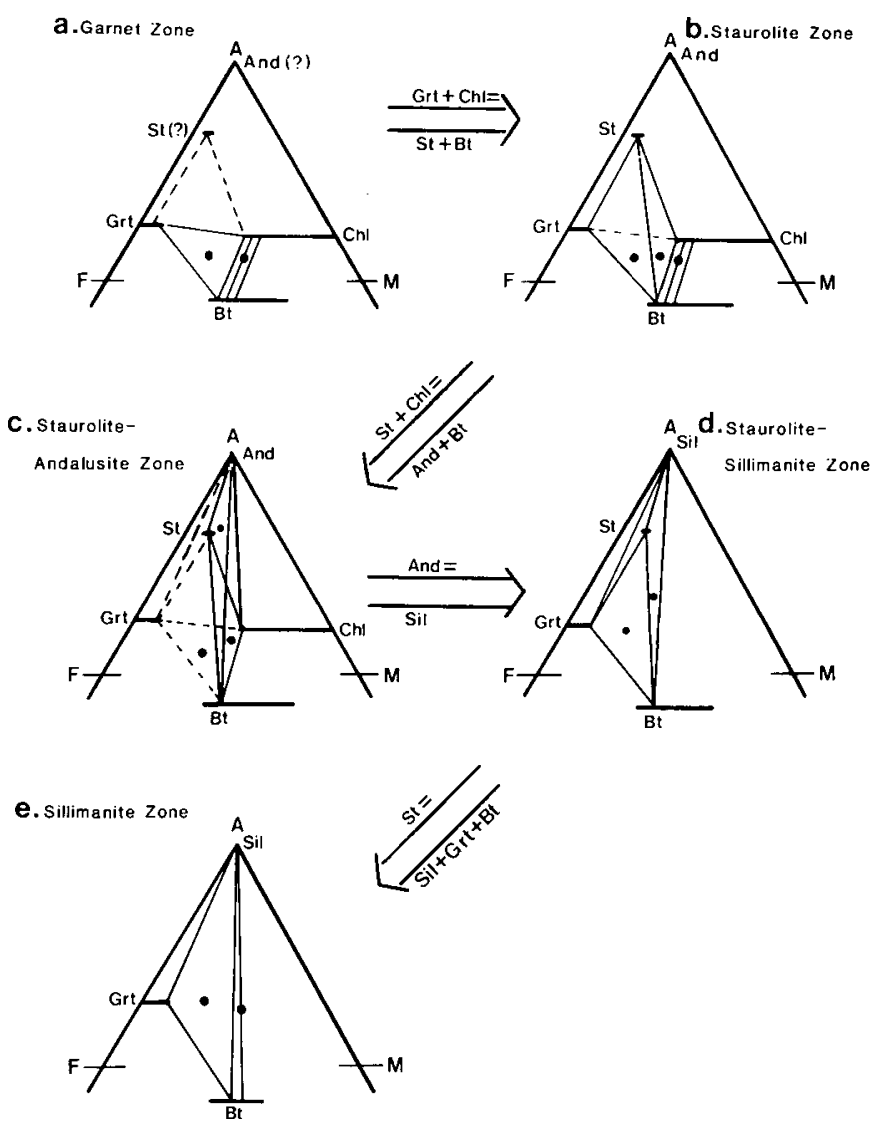

Fig. 4. Schematic AFM diagrams for each zone in the Orrs IslandHarpswell Neck area. Mineral compositions are schematic and are based on those commonly reported in the literature. Dots represent observed assemblages. Tie-lines to garnet in (c) are dashed because gamet is probably stabilized by extra components. Generalized isograd reactions between zones are shown on the large arrows. (For mineral abbreviations, see the caption of Figure 1.)

similar to reaction (2) above.

The transition from the staurolite-sillimanite to the sillimanite zone occurs by disappearance of staurolite from the AFM diagram (Fig. 4d, e). The disappearance of staurolite is described by a reaction of the form:

$$
\mathrm{St}+\mathrm{Qtz}+\mathrm{Ms}=\mathrm{Sil}+\mathrm{Grt}+\mathrm{Bt}+\mathrm{H}_{2} \mathrm{O}
$$

Staurolite in the sillimanite zone is rimmed by coarse-grained muscovite, like andalusite in the staurolite-sillimanite zone. Thus, replacement of staurolite is indirect and may involve coupled ion-exchange reactions like those described by Carmichael (1969).

\section{CONDITIONS OF METAMORPHISM}

Compositions of minerals in samples from the Orrs IslandHarpswell Neck area have not been determined; therefore, cation exchange geothermometry and geobarometry cannot be used to estimate metamorphic conditions. Metamorphic conditions for the study area can be estimated on the basis of petrogenetic grid geothermometry (Fig. 5), which is well constrained in the applicable region of pressure-temperature space. Applicable reactions have been placed in pressure $(\mathrm{P})$-temperature $(T)$ space on the basis of laboratory experiments and thermodynamic calcula- 


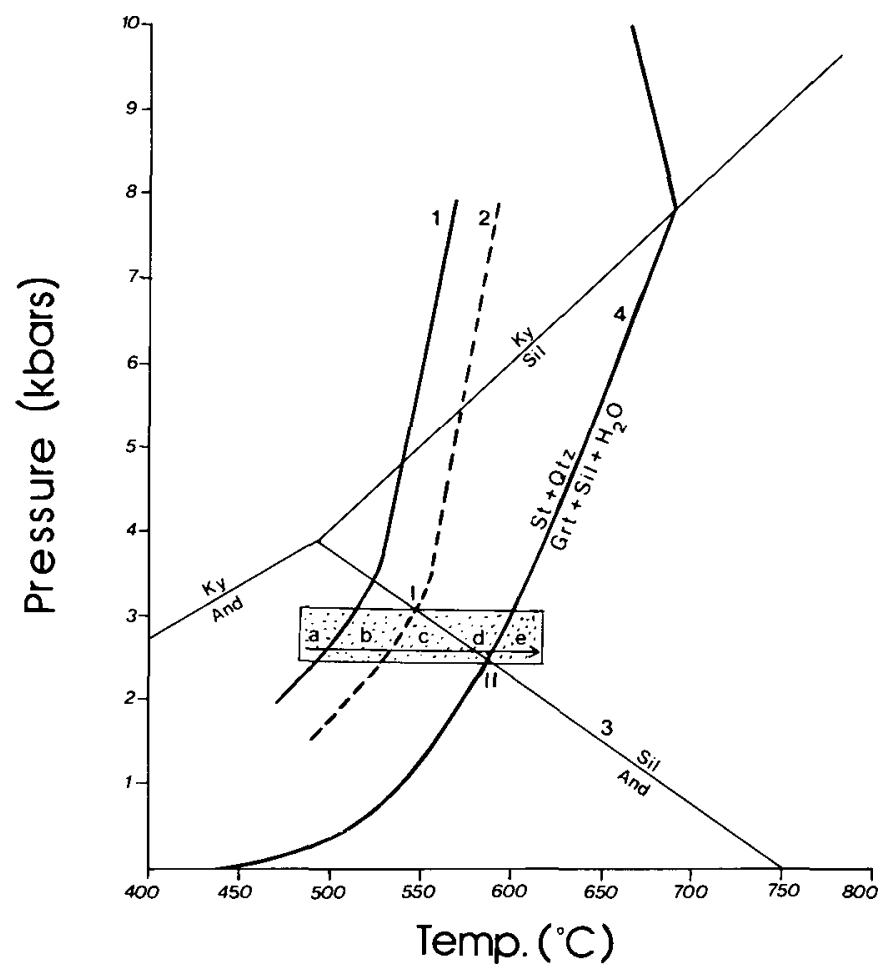

Fig. 5. Petrogenetic grid showing conditions of metamorphism in the Orrs Island-Harpswell Neck area. Reaction 1: $\mathrm{Grt}+\mathrm{Chl}=\mathrm{St}+\mathrm{Bt}$; Reaction 2: $\quad \mathrm{St}+\mathrm{Chl}=\mathrm{Al}_{2} \mathrm{SiO}_{5}+\mathrm{Bt}$. (See text for discussion of the placement of reactions on the petrogenetic grid.) The stippled box shows the estimated range of metamorphic conditions across the area (a: Grt zone, b: St zone, c: St-And zone, d: St-Sil zone, e: Sil zone). The arrow represents the metamorphic field gradient.

tions. In order to simplify the positioning of the reactions, it is assumed that $\mathrm{PH}_{2} \mathrm{O}=\mathrm{P}_{\text {total }}$.

Alumino-silicate phase relations (Holdaway, 1971) place some constraints on metamorphic conditions, because andalusite and sillimanite, but not kyanite, are observed in pelites in the study area. Staurolite disappears in the northeastern portion of the study area, indicating that P-T conditions above the staurolite-breakdown reaction (4) were reached during metamorphism. The staurolite-breakdown reaction (4) has been the subject of several experimental studies (Richardson, 1968; Ganguly, 1972; Rao and Johannes, 1979; Dutrow and Holdaway, 1983). Pigage and Greenwood (1982) determined by linear programming that most of the experimental data of these studies are internally consistent, if the $2(\mathrm{OH}) / 2 \mathrm{Fe}$ staurolite formula $\left(\mathrm{Fe}_{2} \mathrm{Al}_{9} \mathrm{Si}_{3.25} \mathrm{O}_{22}(\mathrm{OH})_{2}\right)$ is used. The position of reaction (4) on Figure 6 was calculated with the program GEOCALC of Berman et al. (1987) using thermodynamic data based on the above experiments. Many investigators (e.g., Pigage and Greenwood, 1982; Lang and Rice, 1985c; Holdaway et al., 1988) have found that the experimentally derived position of this reaction is at a higher temperature than indicated by geothermometry and other considerations. Therefore, the natural staurolite-breakdown reaction may occur at somewhat lower temperature than shown in Figure 5.

Another discontinuous reaction observed in the study area is the staurolite-forming reaction (1). Few experiments have been undertaken on this reaction, and it is compositionally dependent; thus its position in P-T space is poorly constrained. Reaction (1) was positioned on Figure 5 on the basis of experimental data from Hoschek (1969). Hoschek (1969) used minerals with compositions typical of medium-grade pelites in his experiments. If the compositions of the minerals in the study area differ from those used by Hoschek (1969), the position of reaction (1) may shift slightly on the grid; however, reaction (1) must be between the $\mathrm{Al}_{2} \mathrm{SiO}_{5}$ triple point and reaction (4).

The position of the andalusite-forming reaction (2) has not been experimentally determined. Reaction (2) must be at a higher temperature than reaction (1). The temperature increment between reactions (1) and (2) in Figure 5 is based on the width of the metamorphic zones in the field area and is only approximate. Reaction (2) was arbitrarily drawn parallel to reaction (1). The position of reaction (2) is dependent on the positions of reactions (1) and (4), and thus inherits the uncertainties in the positions of those reactions (Fig. 5).

Equilibrium metamorphic assemblages from each zone in the field area have been placed on the petrogenetic grid (a-e on Fig. 5). These assemblages probably represent the maximum temperature achieved by each rock along its metamorphic path ("peak metamorphic conditions"; Spear et al., 1984). The arrow connecting these points in P-T space represents the metamorphic field gradient (Spear et al., 1984) for rocks of the study area. Textural analysis (Dunn, 1988; Lang and Dunn, in preparation) suggests that in this area the metamorphic field gradient may closely approximate the P-T path.

The range of peak metamorphic conditions in the study area is shown by the stippled area in Figure 5. The minimum pressure is constrained by the intersection of reaction (3) with reaction (4) (II on Fig. 5), because andalusite begins to break down to sillimanite before staurolite+quartz breaks down (Bathozone 3 of Carmichael, 1978). The maximum pressure is constrained by the intersection of reaction (2) and reaction (3) (I on Fig. 5), because in the study area staurolite+chlorite reacted to form andalusite, not sillimanite. Based on the positions of the reactions on Figure 5, the estimated pressure range is 2.3 to $3.0 \mathrm{kbars}$ (230 to $300 \mathrm{MPa}$ ). Because of the uncertainty in placing reaction (2) in P-T space, the maximum pressure could have been slightly higher.

The estimated range in peak temperature for each zone in the study area is as follows: $\angle 500^{\circ} \mathrm{C}$ for the garnet zone (a), 500 to $530^{\circ} \mathrm{C}$ for the staurolite zone (b), 530 to $570^{\circ} \mathrm{C}$ for the stauroliteandalusite zone (c), 570 to $590^{\circ} \mathrm{C}$ for the staurolite-sillimanite zone (d), and $>590^{\circ} \mathrm{C}$ for the sillimanite zone (e). The maximum temperature for rocks in the study area (sillimanite zone) is above the staurolite-breakdown reaction (4) at approximately $600^{\circ} \mathrm{C}$. This temperature may be somewhat high because of the problems with reaction (4).

\section{REGIONAL INTERPRETATIONS}

Although multiple metamorphic events have been documented in other parts of Maine, the Orrs Island-Harpswell Neck area was apparently affected by only one major prograde metamorphic event. This event produced metamorphic assemblages that can be divided into a gamet zone, staurolite zone, staurolite- 
andalusite zone, staurolite-sillimanite zone, and sillimanite zone. Coarse-grained muscovite pseudomorphs occur only where andalusite or staurolite broke down to form sillimanite as a result of progressive metamorphism (Guidotti, 1968). The major metamorphic event was synchronous with $\mathrm{D}_{2}$, and porphyroblasts contain relicts of progressive transposition of the $S_{1}$ schistosity into an $\mathrm{S}_{2}$ schistosity by development of crenulation cleavage. Metamorphic grade increases from SW to NE toward a series of Devonian(?) plutons (Hussey, 1985). The age of these plutons suggests that metamorphism and $\mathrm{D}_{2}$ deformation in the Orrs Island-Harpswell Neck area were Acadian in age. Recently determined ${ }^{40} \mathrm{Ar} /{ }^{39} \mathrm{Ar}$ hornblende cooling ages (West et al., 1988) of approximately $350 \mathrm{Ma}$ for rocks from the study area are also consistent with Acadian metamorphism.

Holdaway et al. (1982) identified four metamorphic events that affected west-central Maine. The second event $\left(M_{2}\right)$ was a regional metamorphic event that produced staurolite, andalusite, locally cordierite, but no sillimanite and showed no obvious relation to exposed plutons. In some areas, rocks affected by $\mathrm{M}_{2}$ were affected by a third regional metamorphic event $\left(M_{3}\right)$, which occurred at slightly higher pressure than $\mathrm{M}_{2}$. Metamorphism during $M_{3}$ in west-central Maine involved staurolite+chlorite and sillimanite and was related to the intrusion of plutonic rocks; however, andalusite and cordierite were not observed. Progressive metamorphism in the Orrs Island-Harpswell Neck area is most similar to $M_{3}$ in west-central Maine (Holdaway et al., 1982), because both events occurred at pressures where staurolite gives way to sillimanite at high grade, and both events are related to plutons. Metamorphism in the study area differs from $\mathrm{M}_{3}$ of Holdaway et al. (1982) and resembles $M_{2}$ because it did produce andalusite. These observations are consistent with the model of Lux et al. (1986), which related high-grade metamorphism in Maine to emplacement of plutons of different ages. According to this model, metamorphism would not be expected to be synchronous or of exactly the same character throughout the region.

\section{ACKNOWLEDGEMENTS}

This research represents a portion of Dunn's M.S. thesis submitted to West Virginia University. We would like to thank C.V. Guidotti for encouraging us to work in Maine, and A.M. Hussey II for assistance in the field. W.M. Dunne and J.S. Kite reviewed an earlier version of the manuscript. Thoughtful reviews by A.M. Hussey II and C.V. Guidotti improved the final presentation. Financial support was provided by a Sigma Xi Research Grant and a Student Research Grant from the Department of Geology and Geography, West Virginia University.

BELL, T.H. and RUBENACH, M.J. 1983. Sequential porphroblast growth and crenulation cleavage development during progressive metamorphism. Tectonophysics, 92, pp. 171-192.

BELL, T.H., RUBENACH, M.J., and FLEMING, P.D. 1986. Porphyroblast nucleation, growth and dissolution in regional metamorphic rocks as a function of deformation partitioning during foliation development. Journal of Metamorphic Geology, 4, pp. 37-67.

BERMAN, R.G., BROWN, T.H., and PERKINS, E.H. 1987. GE0CALC Software for calculation and display of pressure-tempera- ture-composition phase diagrams. University of British Columbia. CARMICHAEL, D.M. 1969. On the mechanism of prograde metamorphic reactions in quartz-bearing pelitic rocks. Contributions to Mineralogy and Petrology, 20, pp. 244-269.

1970. Intersecting isograds in the Whetstone Lake area, Ontario. Journal of Petrology, 11, pp. 147-181.

. 1978. Metamorphic bathozones and bathograds: a measure of the depth of post-metamorphic uplift and erosion on the regional scale. American Journal of Science, 278, pp. 769-797.

CHAMBERLAIN, C.P. and LYONS, J.B. 1983. Pressure, temperature, and metamorphic zonation studies of pelitic schists in the Merrimack Synclinorium, south-central New Hampshire. American Mineralogist, 68, pp. 530-540.

DUNN, G.R. 1988. Low pressure metamorphism in the Ors IslandHarpswell Neck area, Maine. Unpublished M.Sc. thesis, West Virginia University, Morgantown, West Virginia, 96 p.

DUTROW, B.L. and HOLDAWAY, M.J. 1983. Upper stability of staurolite+quartz at low pressures. Geological Society of America, Abstracts with Programs, 15, p. 563.

GANGULY, J. 1972. Staurolite stability and related paragenesis: theory, experiments, and applications. Journal of Petrology, 13, pp. 335-365.

GUIDOTTI, C.V. 1968. Prograde muscovite pseudomorphs after staurolite in the Rangely-Oquossoc areas, Maine. American Mineralogist, 53, pp. 1368-1376.

1970a. The mineralogy and petrology of the transition from the lower to upper sillimanite zone in the Oquossoc area, Maine. Journal of Petrology, 11, pp. 277-336.

- 1970b. Metamorphic petrology, mineralogy and polymetamorphism of a portion of NW Maine. In Guidebook Field Trip B2: New England Intercollegiate Geological Conference. Edited by G.M. Boone. Pp. 1-29.

. 1974. Transition from staurolite to sillimanite zone, Rangely Quadrangle, Maine. Geological Society of America Bulletin, 85, pp. $475-490$.

1985. Generalized map of regional metamorphic zones. In Bedrock geologic map of Maine. Edited by P.H. Osberg, A.M. Hussey and G.M. Boone. Department of Conservation, Maine Geological Survey, Open File No. 84-1, 1:500,000.

GUIDOTTI, C.V., GIBSON, D., LUX, D.R., DeYOREO, J., and CHENEY, J.T. 1986. Carboniferous metamorphism on the north (upper) side of the Sebago Batholith. In Guidebook Field TripC4: New England Intercollegiate Geological Conference. Edited by D.W. Newberg. Pp. 306-341.

GUIDOTTI, C.V., TRZCIENSKI, W.E., and HOLDAWAY, M.J. 1983. A northern Appalachian metamorphic transect-eastem townships Quebec to the central Maine coast. In Regional trends in the geology of the Appalachian-Hercynian-Mauritanide Orogen. Edited by P.E. Schenk. D. Reidel Publishing Company, New York, pp. 235-247.

HOLDAWAY, M.J. 1971. Stability of andalusite and the aluminosilicate phase diagram. American Journal of Science, 271, pp. 97. 131.

HOLDAWAY, M.J., DUTROW, B.L., and HINTON, R.W. 1988. Devonian and Carboniferous metamorphism in west-central Maine. The muscovite-almandine geobarometer and the staurolite problem revisited. American Mineralogist, 74, pp. 20-47.

HOLDAWAY, M.J., GUIDOTTI, C.V., NOVAK, J.M., and HENRY, W.E. 1982. Polymetamorphism in medium- to high-grade pelitic metamorphic rocks, west-central Maine. Geological Society of America Bulletin, 93, pp. 572-584.

HOSCHEK, G. 1969. The stability of staurolite and chloritoid and their 
significance in metamorphism of pelitic rocks. Contributions to Mineralogy and Petrology, 22, pp. 208-232.

HUSSEY, A.M., II. 1968. Stratigraphy and structure of southwestern Maine. In Studies of Appalachian geology: Northem and Maritime. Edited by E-an Zen. New York Interscience Publishers, Inc., pp. 291-301.

-1971. Geologic map and cross-section of the Orrs Island 7 1/ 2 ' quadrangle and adjacent area, Maine. Maine Geological Survey, Geologic Map Series GM-2.

- 1985. Bedrock geology of the Bath and Portland 2-degree sheets, Maine. Maine Geological Survey, Open File No. 85-87.

HUSSEY, A.M., II, BOTHNER, W.A., and THOMSON, J.A. 1986. Geological comparisons across the Norumbega fault zone, southwest Maine. In Guidebook Field Trip A-4: New England Intercollegiate Geological Conference. Edited by D.W.Newburg. Pp.350370.

KATZ, F.J. 1917. Stratigraphy in southeasten New Hampshire and southwesten Maine. United States Geological Survey, Professional Paper 108, pp. 11-29.

KRETZ, R. 1983. Symbols for rock-forming minerals. American Mineralogist, 68, pp. 277-279.

KWAK, T.A.P. 1971. The selective replacement of the alumino silicates by white mica. Contributions to Mineralogy and Petrology, 32, pp. 193-210.

LANG, H.M. and RICE, J.M. 1985a. Metamorphism of pelitic rocks in the Snow Peak area, Northern Idaho: Sequence of events and regional implications. Geological Society of America Bulletin, 96, pp. 731-736.

- 1985b. Regression modelling of metamorphic reactions in metapelites, Snow Peak, Northem Idaho. Joumal of Petrology, 26, pp. 857-887.

- 1985c. Geothermometry, geobarometry, and T-X(Fe-Mg) relations in metapelites, Snow Peak, Northern Idaho. Joumal of Petrology, 26, pp. 889-924.

LUX, D.R., DeYOREO, J.J., GUIDOTTI, C.V., and DECKER, E.R. 1986. Role of plutonism in low-pressure metamorphic belt formation. Nature, 323, pp. 794-797.

LUX, D.R. and GUIDOTTI, C.V. 1985. Evidence for extensive Hercynian metamorphism in western Maine. Geology, 13, pp. 696-700.

MOHR, O.W., BARNETT, R.L., and MICHIE, J. 1986. Chemical processes and migration of elements during retrogression of a staurolite-zone assemblage in western North Carolina. Contributions to Mineralogy and Petrology, 92, pp. 400-411.

NOVAK, J.M. and HOLDAWAY, M.J. 1981. Metamorphism, petrology, mineral equilibrium and polymetamorphism in the Augusta quadrangle, south-central Maine. American Mineralogist, 66, pp. 51-69.

OSBERG, P.H. 1968. Stratigraphy, structural geology and metamorphism of the Waterville-Vassalboro area, Maine. Maine Geological Survey Bulletin, 20,64 p.

. 1971. An equilibrium model for Buchan-type metamorphic rocks, south-central Maine. American Mineralogist, 56, pp. 570 586.

1974. Buchan type metamorphism of the Waterville pelite, south-central Maine. Guidebook Field Trip B-6: New England Intercollegiate Geological Conference, pp. 210-222.

OSBERG, P.H., HUSSEY, A.M., and BOONE, G.M. 1985. Bedrock geologic map of Maine. Department of Conservation, Maine Geological Survey, Open File No. 84-1, 1:500,000.

PIGAGE, L.C. and GREENWOOD, H.J. 1982. Internally consistent estimates of pressure and temperature: The staurolite problem. American Journal of Science, 282, pp. 943-969.

RAO, B.B. and JOHANNES, W. 1979. Further data on the stability of staurolite + quartz and related assemblages. Neues Jahrbuch Mineralogie Monatsheft, pp. 437-447.

RICHARDSON, S.W. 1968. Staurolite stability in a part of the system Fe-Al-Si-O-H. Joumal of Petrology, 9, pp. 467-484.

SPEAR, F.S. and CHENEY, J.T. 1986. Yet another petrogenetic grid for pelitic schists. Geological Society of America, Abstracts with Programs, 18, p. 758.

SPEAR, F.S., SELVERSTONE, J., HICKMOTT, D., CROWLEY, P., and HODGES, K.V. 1984. P-T paths from garnet zoning: A new technique for deciphering tectonic processes in crystalline terranes. Geology, 12, pp. 87-90.

THOMPSON, J.B. 1957. The graphical analysis of mineral assemblages in pelitic schists. American Mineralogist, 42, pp. 842-858.

THOMPSON, J.B. and NORTON, S.A. 1968. Paleozoic regional metamorphism in New England and adjacent areas. In Studies of Appalachian Geology: Northern and Maritime. Edited by E-an Zen. New York Interscience Publishers, Inc., pp. 319-325.

THOMSON, J.A. 1985. The occurrence of kyanite in southern Maine and its metamorphic implications. Unpublished M.Sc. thesis, University of Maine, Orono, Maine, 128 p.

THOMSON, J.A. and GUIDOTTI, C.V. In press. Carboniferous Barrovian metamorphism in southern Maine. C.T. Jackson Memorial Volume, Maine Geological Survey.

VERNON, R.H.. 1977. Relationships between microstructures and metamorphic assemblages. Tectonophysics, 39, pp. 439-452.

WEST, D.P., Jr., LUX, D.R., and GUIDOTTI, C.V. $1988 .{ }^{40} \mathrm{Ar}{ }^{\beta 9} \mathrm{Ar}$ mineral ages from the Casco Bay Group, southwestern Maine. Geological Society of America, Abstracts with Programs, 20, p. 78. 